CIHM Microfiche Series (Monographs)
ICMH

Collection de microfiches (monographies)

Canadian Institute for Mistorical Microreproductions / Institut canadien de microreproductions historiques
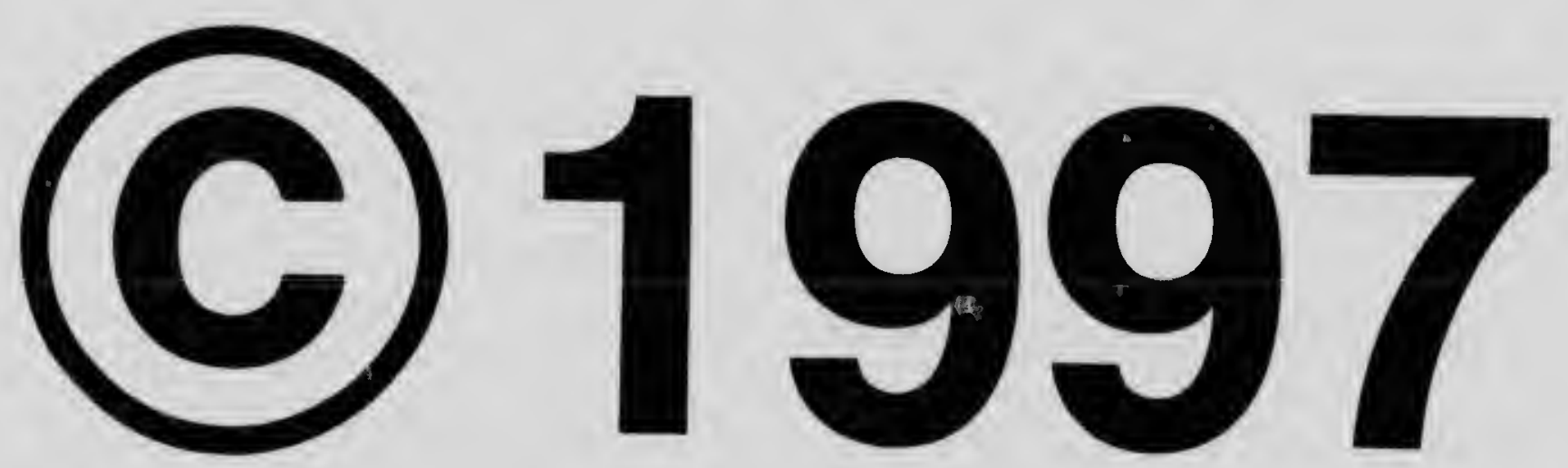


\section{Technical and Bibliographic Notes / Notes techniques et bibliographiques}

The Institute has attempted to obtain the best original copy available for filming. Features of this copy which may be bibliographically unique, which may alter any of the images in the reproduction, or which may slgnificantly change the usual method of filming are checked below.

\section{Coloured covers $/$ \\ Couverture de couleur}

Covers damaged /

Couverture endommagée

Covers restored and/or laminated /

Couverture restaurée et/ou pelliculée

Cover title missing / Le titre de couverture manque

Coloured miaps / Cartes géographiques en couleur

Coloured ink (i.e. other than blue or black) /

Encre de couleur (i.e. autre que bleue ou noire)

Coloured plates and/or illustrations /

Planches etou illustrations en couleur

Bound with other material /

Relié avec d'autres documents

Only edition available /

Seule édition disponible

Tight binding may cause shadows or distortion along interior margin / La reliure serrée peut causer de l'ombre ou de la distorsion le long de la marge intérieure.

Blank leaves added during restorations may appear within the text. Whenever possible, these have been omitted from filming / II se peut que certaines pages blanches ajoutées lors d'une restauration apparaissent dans le texte, mais, lorsque cela était possible, ces pages n'ont pas été filmées.

Additional comments /

Commentaires supplémentaires:
L'Institut a microfilmé le meilleur exemplaire qu'il lul a été possible de se procurer. Les détails de cet exemplaire qui sont peut-être uniques du point de vue bibliographique, qui peuvent moditier une image reproduite, ou qui peuvent exiger une modification dans la méthode normale de filmage sont indiqués ci-dessous.

\section{Coloured pages / Pages de couleur}

\section{Pages damaged / Pages endommagées}

Pages restored and/or laminated /

Pages restaurées etou pelliculées

Pages discoloured, stained or foxed /

Pages décolorées, tachetées ou piquées

Pages delached / Pages délachées

\section{Showhrough / Transparence}

Quality of print varies /

Qualité inégale de l'impression

Includes supplementary material /

Comprend du matériel supplémentaire

Pages wholly or partially obscured by errata slips, tissues, etc., have been refilmed to ensure the best possible image / Les pages totalement ou partiellement obscurcies par un feuillet d'errata, une pelure, etc., ont été filmées à nouveau de façon à obtenir la meilleure image possible.

Opposing pages with varying colouration or discolourations are filmed twice to enstre the best possible image / Les pages s'opposant ayant des colorations variables ou des décolorations sont filmées deux fois afin d'obtenir la meilleure image possible.

This item is filmed at the reduction ratio checked below I

ce document est filmé au isux do rfduction indiqué ci-dessous.

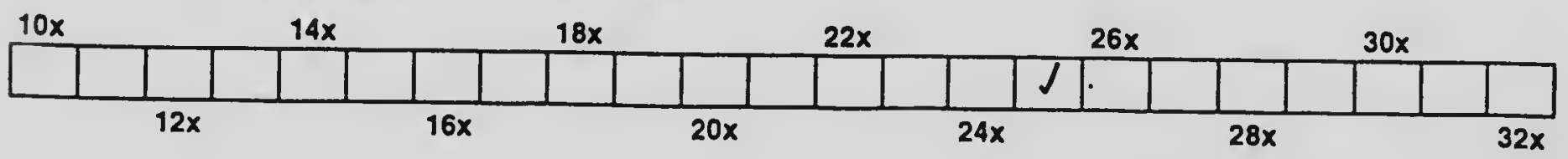


The copy filmed here has been raproducad thanks to the generosity of:

Energy, Mines and Resources Canada Headquarters Library

The images appeaplng here are the best quaity posslble considuring the condition and laglbility of the orlginai copy and in keeping with the fiiming contract spocifications.

Originai copias in printed peper covers are flimad beginning with the front covar and ending on the iast pege with a printed or iilustrated impres. sion, or the beck cover when approprlate. Ail other orlginai copias are fiimod beginning on the first page with a printed or illustratad impres. sion. and anding on the iast page with a printad or iiluserated impression.

The last racorded freme on aech microfiche shell contain the symbol $\longrightarrow$ Imeaning "CON. TINUED"), or the symbol $\nabla$ (maening "END"). whichover appiies.

Maps, pioios, chorts, ate., may be fiimed at differant raduction ratios. Those too large to be entiraiy included in one axposure are filmed beginning in the upper iaft hand corner, iaft to right and top to bottom. as meny frames as required. The foliowing dingrams iilustrete the mothod:
L'axemplaire fiimb fut raproduit grâce a ia odndrosite da:

Energie, wines ot ressources Canada Biblfothique centrale

Les imagas suiventas ont ded reproduites avac la plus grand soin. compte tenu da la condition et de la nottaté de l'exomplaire fiims, et en conformits avoc las condlions du contrat de tiimege.

Las axomplairas originoux dont la couvertura an papiar eat imprimbe sont fiimds en commançant par la pramiar piat ot on terminant soit par la dernidre page qul comporte une empreinta d'Imprassion ou d'illustration. soit per le sacond piot, soion is cas. Tous ias outres examplairas originoux sont fllmbs an commençant par la premidre pege qui comporte une emprainte d'imprassion ou d'iilustration at en tarminant par is dernidre poge qui comporte une talla emprointe.

Un des symbolas suivents apparaitra sur la dernidre image de chaque microfiche, salon la cas: le symbole $\longrightarrow$ signifie "A SUIVRE". le symboie $\nabla$ signifie "FIN".

Las cortes, planches, tabiaaux, atc., peuvant êtra filmbs des taux de roduction diffórants. Lorsque in document ast trop grend pour etra reproduit an un seui clichd, ii ast filmo a partir de l'angie supdriaur gauche. de gaucha a droite. et da hout en bas. en pranant la nombi : d'images ndcassaire. Las diagrammes suivants iivstrent is mothoda.
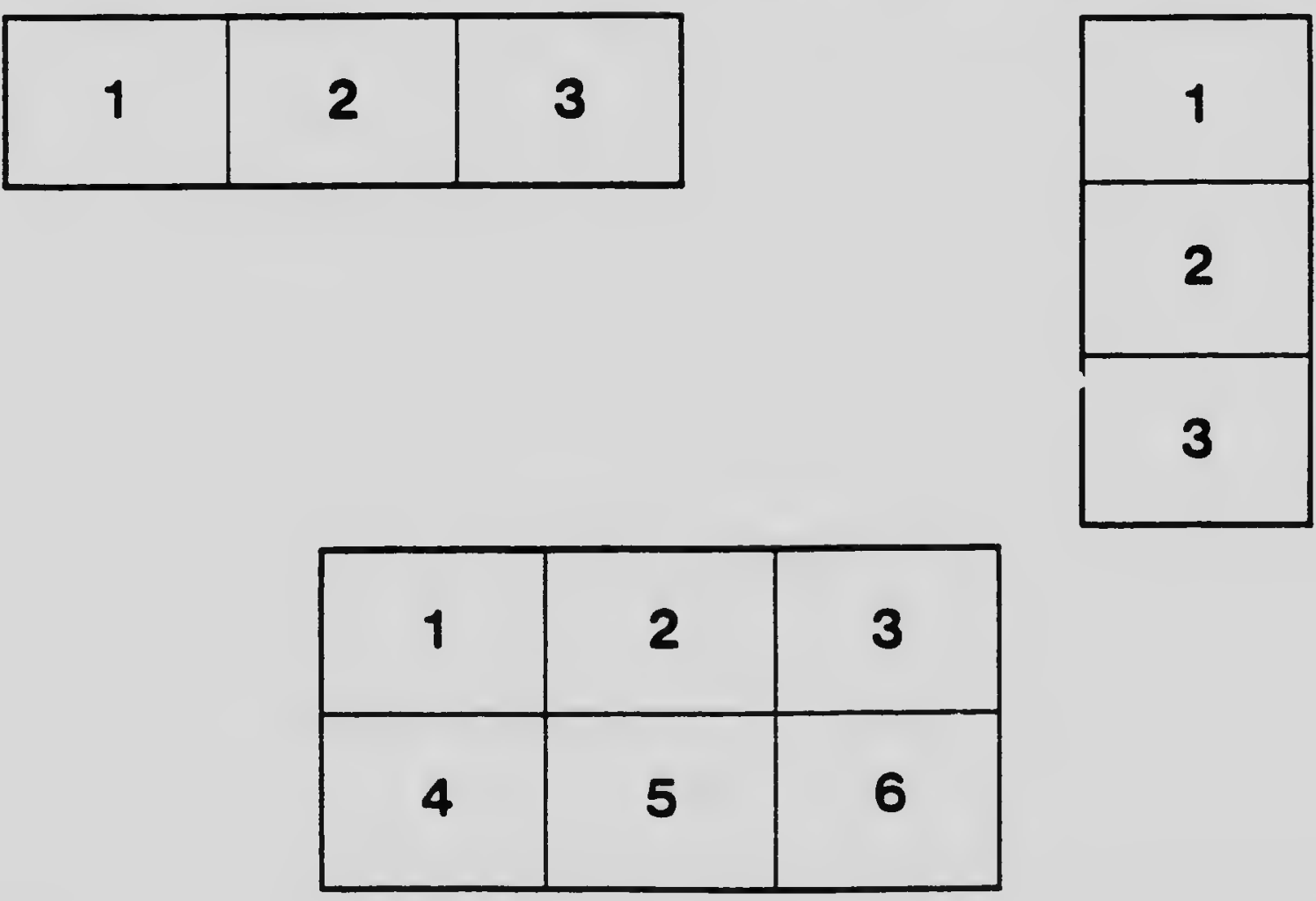
(ANSI and ISO TEST CHART No 2)
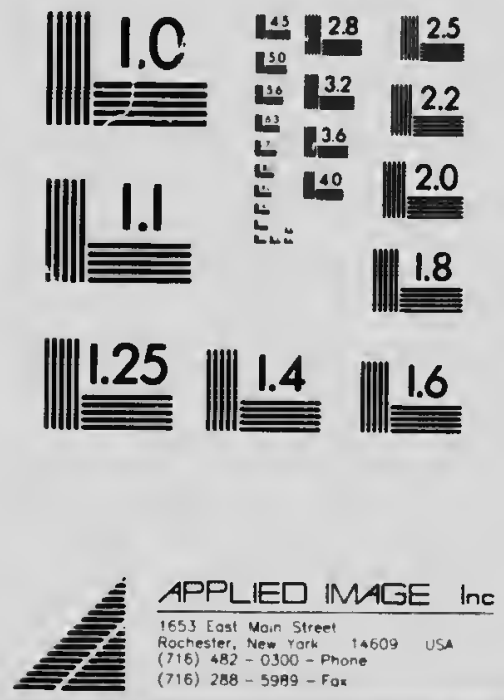


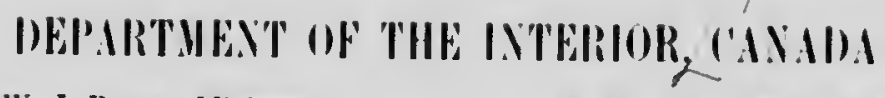

llow. W. J. Rorue, Miniater.

W. W. Cony, Depury Minister.

FORFSTKY HRANCII CIRCUIAR No. 11

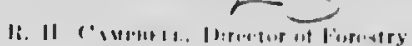

\section{thenvironment Environnement \\ $0015975 \mathrm{~K}$}

CANADA. FURESTRY BRANCH.

\section{The Relation of Forestry to the Development of the Country}

R. H. CAMPIBEI.I. 
$-$ 


\title{
The Relation of Forestry to the Development of the Country.
}

\author{
Description of Bome European Forest Conditions by Mr, R. H. Campbell, Dominion \\ Director of Forestry.
}

While an a risit to tho (14, a 'unutry

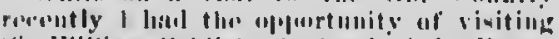
Nir Williane s.hliela, the henel of the Horest

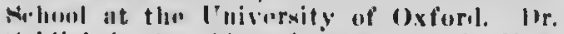
firlalielo is tho olifest forrester now ill Fing. latul and has hat the longest experionese iil forcestry work. lle lial tha liwnor, witlı

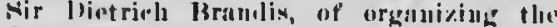

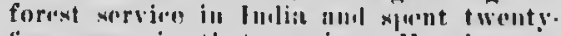
five seare in that sorvines. Ho theol ro. turmol to Finglanil to the torest soliowl

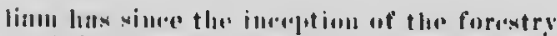
work in cillulin takun a bery kasll interent

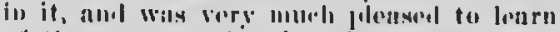

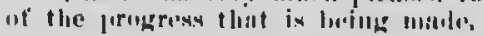

\section{Dr. Schlich Discusses Forestry situation} in Canada.

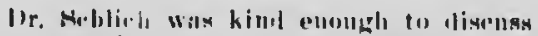
tho f analian situation sumewhat fully,

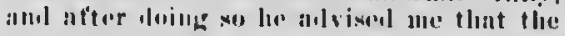

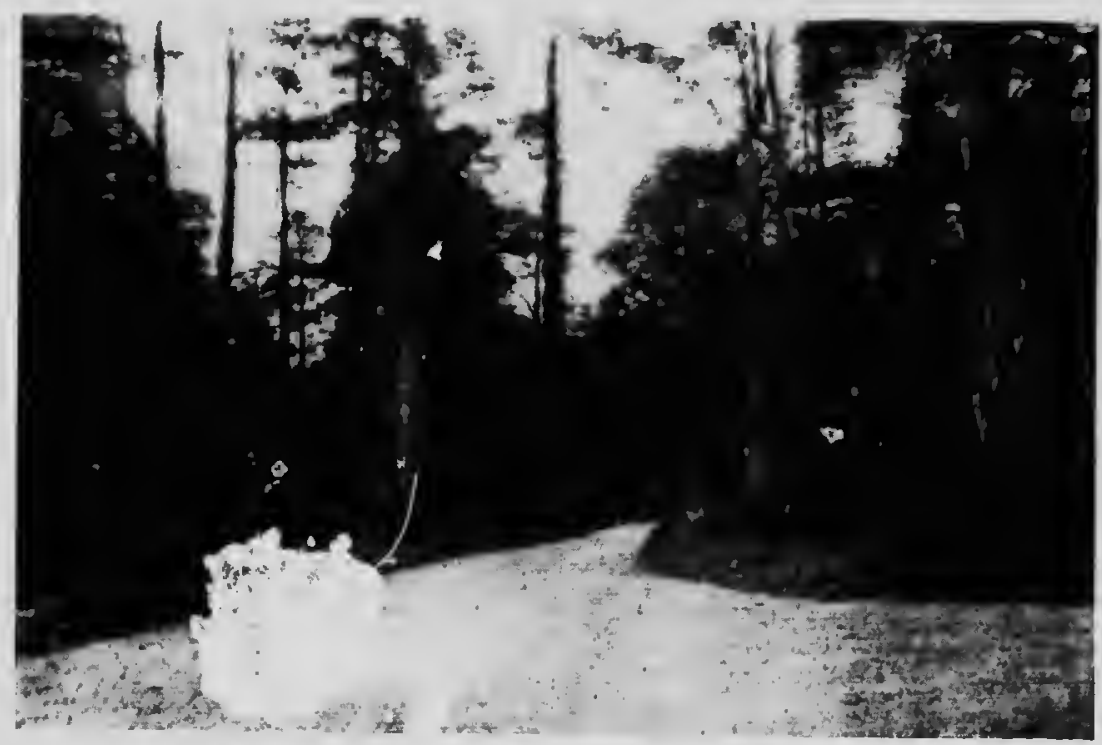

Mature Scotch Pine, Ballochbuie Forest, scotland.

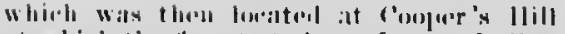
at whiclo the torost stuileuts for the Iuslian servide wore miluratuil, and his vilue lewll engigel in jorparing men for the lulian torest servine, which reopuires very light terhnieral epualifiantions in its of fiecrs. W'ithin the last few years the forrest wahool was movel to Oxford and is now being carriel on ill connection with the Uni. versity. Sir William is still artive ant able to attemd to his work in the solool and deliver leetures, althougl, he is hepill. ning to feel the effects of age. Sir Wil. leses polieg to follow was to lative forest reserves extalolishool wherover there were lands suitalie for that purpuse, and then go forwaril and develop a permanent poliry of alministration on these reserves. This was the joliry followel in the levelop. ment of forestry work in India, and from I)r. Sillich'y experience he was satisfiel thit this was the important basis for any advance in forest management in Canala. A statement of this kind from a man of Nir William Schlieh's long experience both in forest management and in ellucation, is 


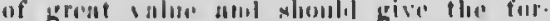

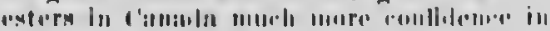

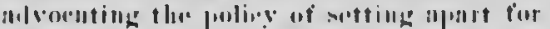

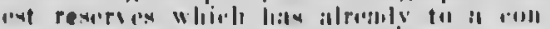

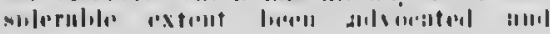
nolpiterl.

\section{Progress Being Made in Setting Apart Forest Reserves.}

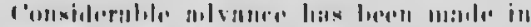

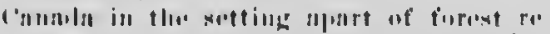

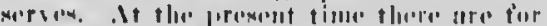

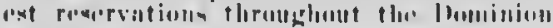
us follows:

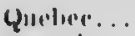

Iistario....

Msutohn...

Mankntrlienail.

Allirrtil...

|Britislı columul,in (in linilwas

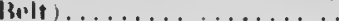

Britinh ('ulumbiat (unt sillo

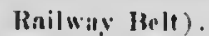

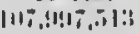

$11,1: 311,7: 21$

$\because$,Iithi, 1Hu

ii, $191, i, 711,1,0$

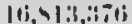

$\because, 11 ;, 1 ; i 4,1$

$\because, 41, \because 211$

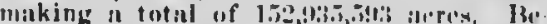
silles the arrens given for Britisli l'ulumbin,

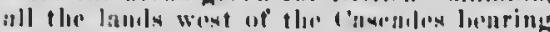

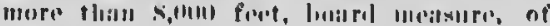

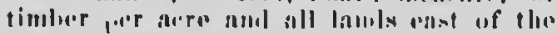

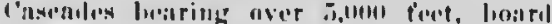

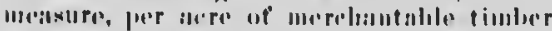
are remusel from entre.

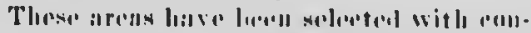

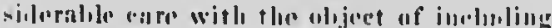

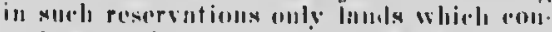
trol witersleds, or whigls awing tu the

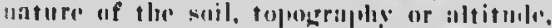

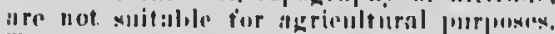

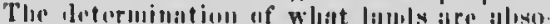

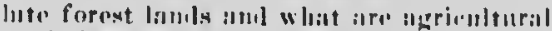
lamis is il matter of geroit importamen, alld

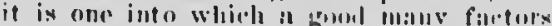
inter sut that the dereision that inle land

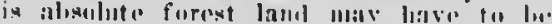

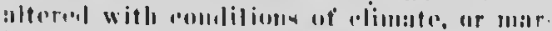
kete alul of agrioultural ilmi furest in. velopiment.

\section{Agricultural Conditions.}

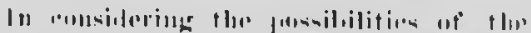

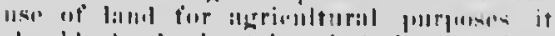

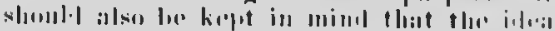

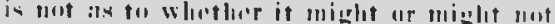

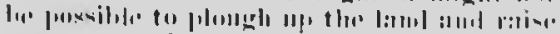

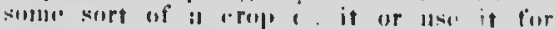

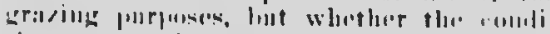
tiuns are smeh that a fomily rall lon -

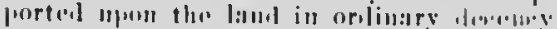

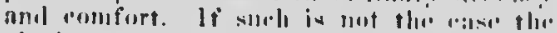

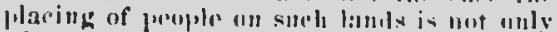

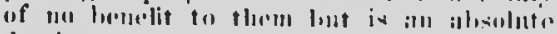

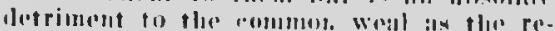

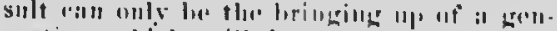
eration whiels will lie a menture ratler shan a strength to the state.

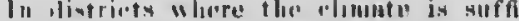

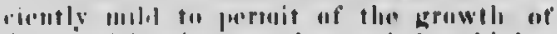

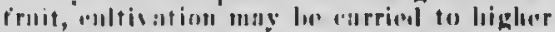

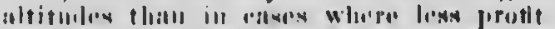

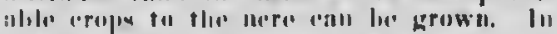

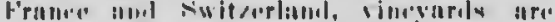

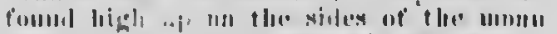

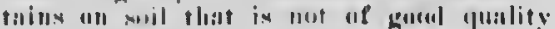

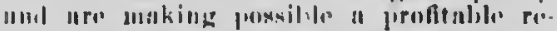

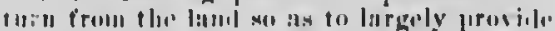

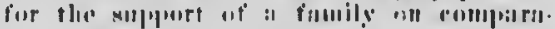

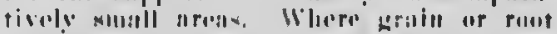

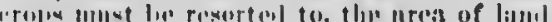
repluirent fur the suppurt of a family wombl

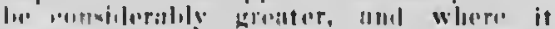

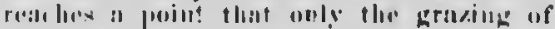

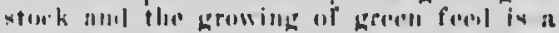

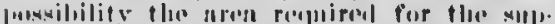

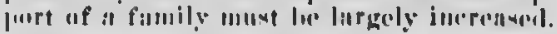

(1) tha formerer land and in the mountain

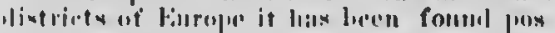
sible to gresitly extend the area of pirofic.

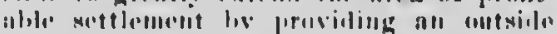

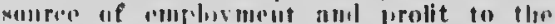

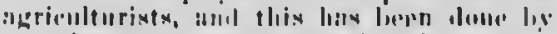
"ovorillg the jour lillol with forest allil - Iothing the monutioinsilde with a erule of

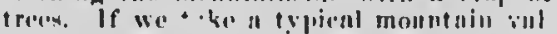

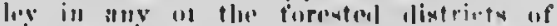
litron the matter will le fouml t, work

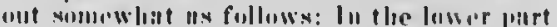

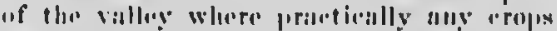

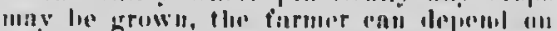
the prowerels of the lana las owne or has

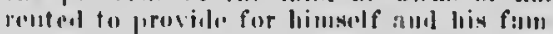

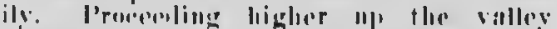

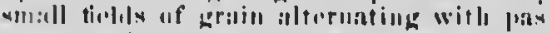

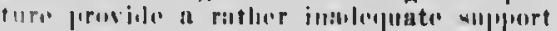

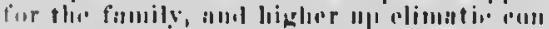

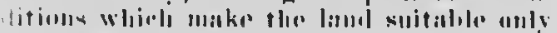

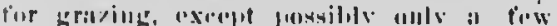

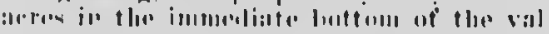

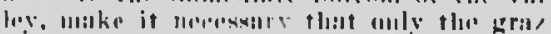

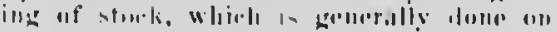

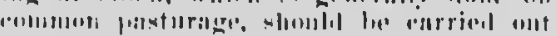

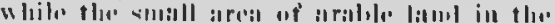

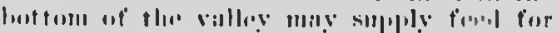

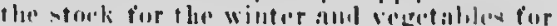
tho' fimily.

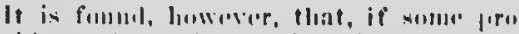

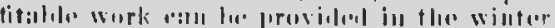
fur the folllilies liville ill sill.

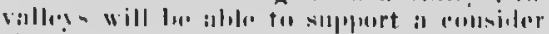

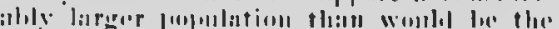

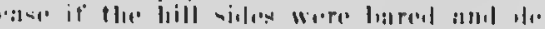

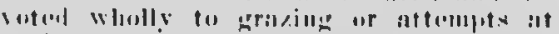

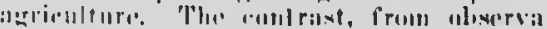

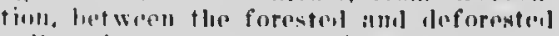

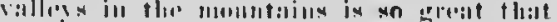

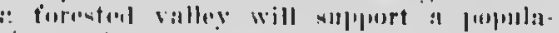
fioll astimaterl at five times the mombler ill : Ileforewfol villere in a monntainous diefriot. It will lu" soren therll that the forrest is nut opposonl to agrionlenres lant is

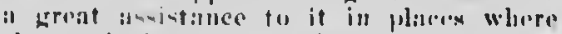
the" agrienltural canditions are not the most falvorable. 


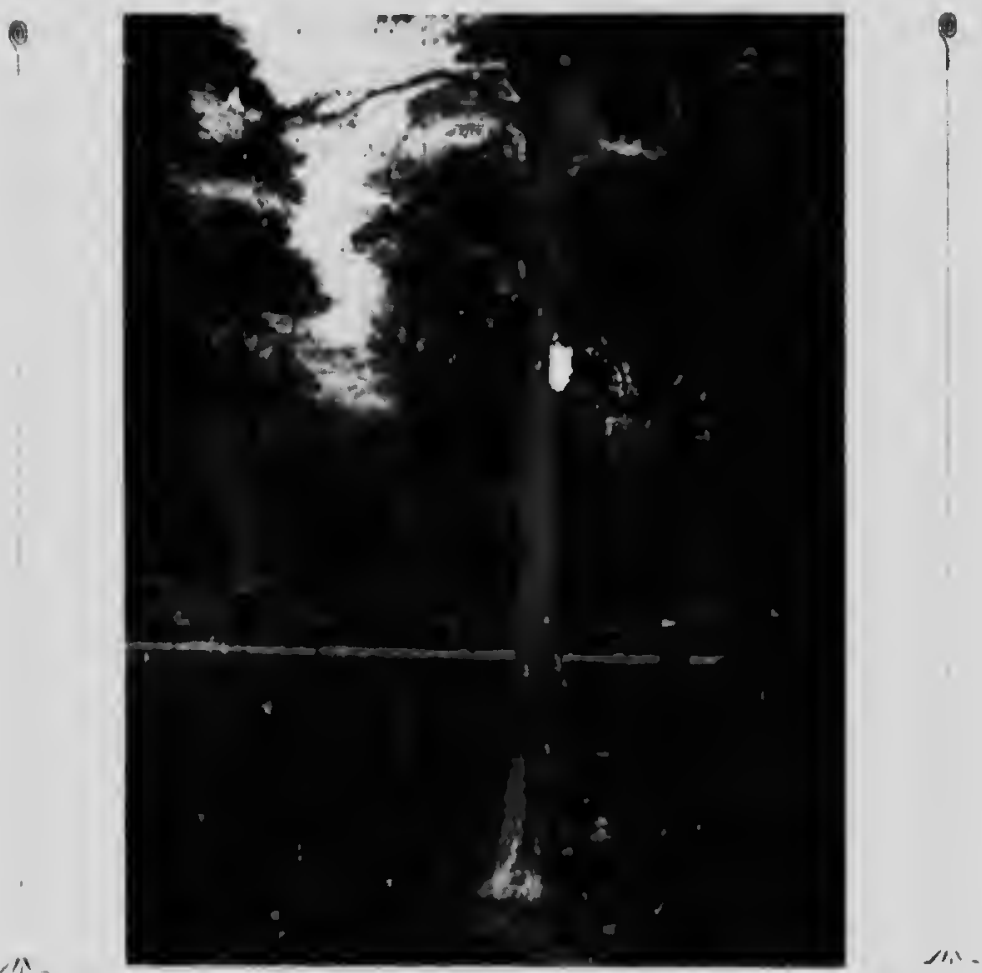

Scotch Pine. Height, 108 feet; girih, 11 feet 10 inches.

\section{Forest Plauting Helps Poor Lands.}

W'lile the agrioultural sottlements in momatain valleys have lenen referrent to in the preostigh paragraph the se thing

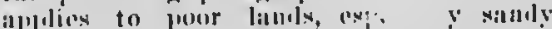

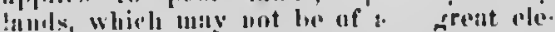

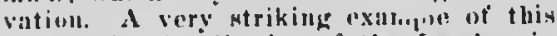
is ste'a in the distriot of the Isamle's in montliwesferu Fralle". 'llie samis thrown

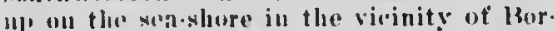
leanx and suntliwaral ariftenl ii on the timmyarils and vitugaris to the rast,

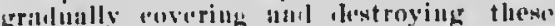
anul resulting in i conlition af sand hills or lumes moving slowly under the influenese of the winl, with stretule's of luarsh les.

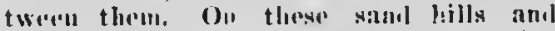
marwhes rrew a saluty veretation vilicel provillol pisturage tur a few sheep whi:l wore lookerl atter liy the shepherils who hate of teu heen leseriled walking over the hills anil through the mirshes on stilts watehing tleeir sleep anil sometimes busily knitting in oriler to allel to the value of their tians. Agriculture was impossible in the distriet and this grazing whiols was very poor aud carrical but a small number of stock was all the use that could bo male of this extensive aul ine reasing waul arcia. In the vesur ligs steps were taken ly the freuti fovernment to aseertain what eould la , lone to improve ennelitions liere, aull a puliey of forest planting was decided ou with the result that these sand wastow have loceu uluont entirely planted up with Mluritime piun whith pirnilues a very vulualule lunrvest of resin iluriug tho life of the tree while the woml afterwarils is used for paving blocks ia laris, for

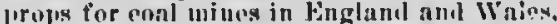
aud for otleer purposes. In fact our part of the shortage at mine uroles in (ireint Jritain at the present time is lue to tlas finet that the suplyly coulal not be olitaineil

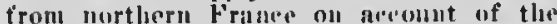
searieity of laber owing to the non having all beril rellefl out to oin the arms. It will he rememlereal that there was a ilepul tation from the British governuent in Can. ada reently looking iuto the question of the possiluility of obtaining a sulplyy of pit props in Cauala to cover "he sliortage from th 13altie as well as from France.

The ffe't on the population of this re. forestation work is slown by the fact that in the parishes of Ia Teste and Cazeaux, in this district the population before re- 


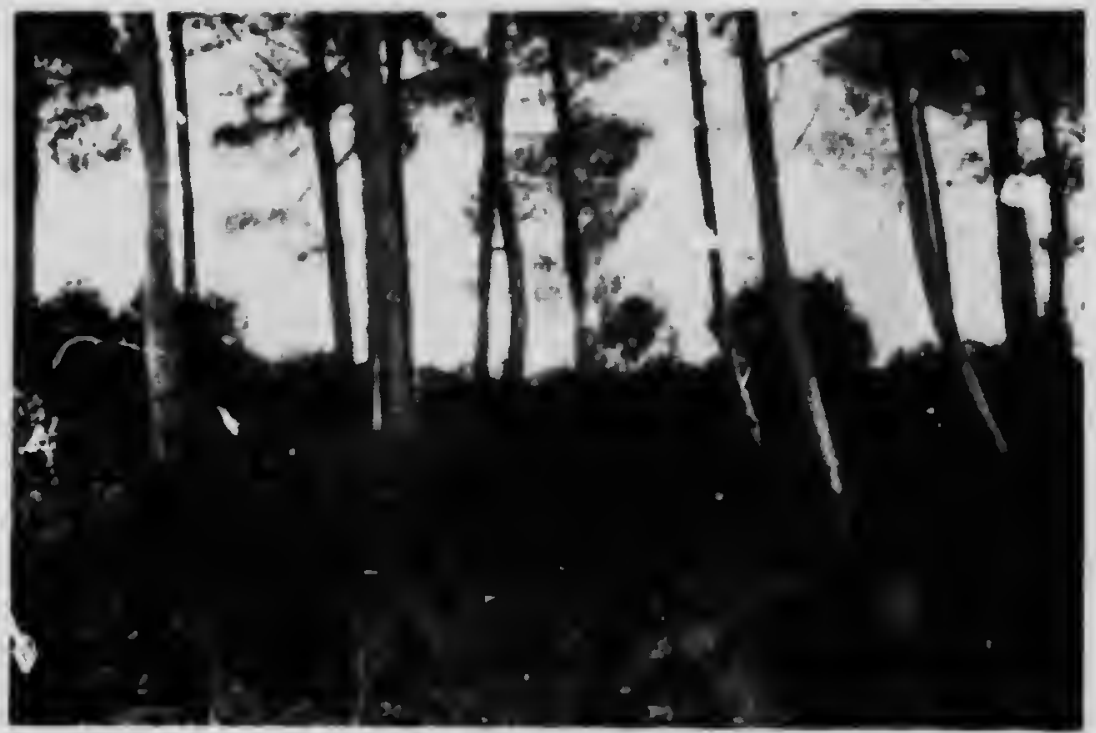

Pine Trees tapped for 'esin near Bordeaux, France.

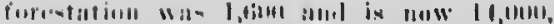

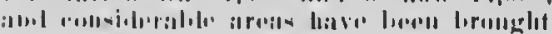

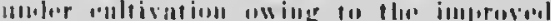

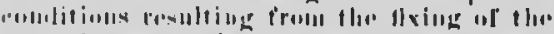

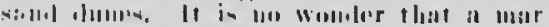

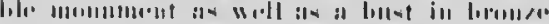

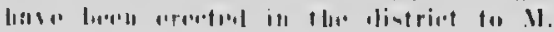

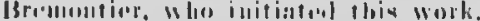

\section{Forestry in Scotland.}

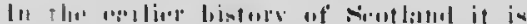

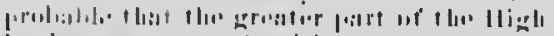

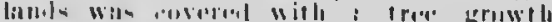

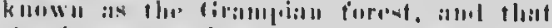

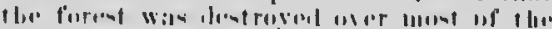

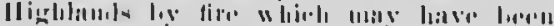

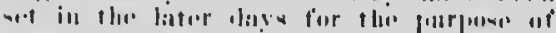

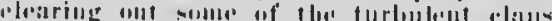

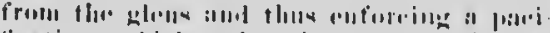

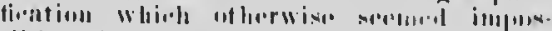

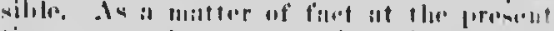

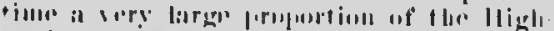

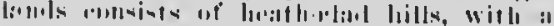

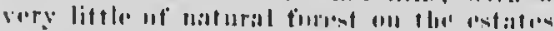

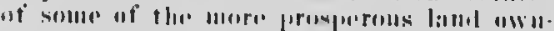

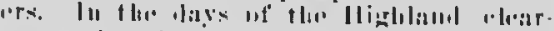

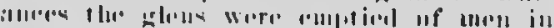

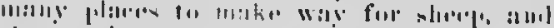

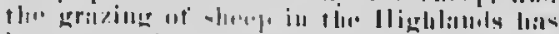

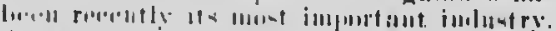

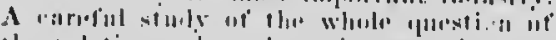

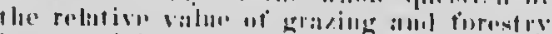

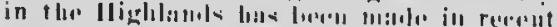

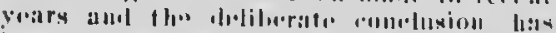
been rearleel that with lanil which will not reut for more flan ouc shilling un stere

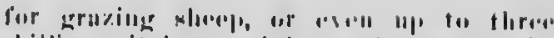

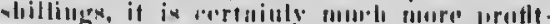

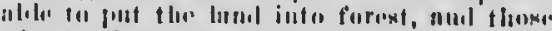

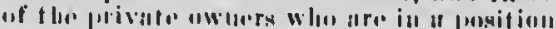

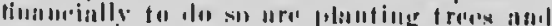

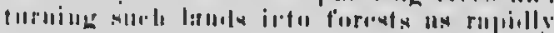

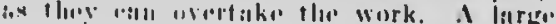

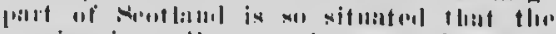

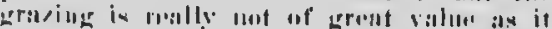

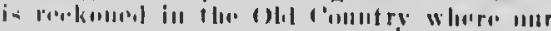

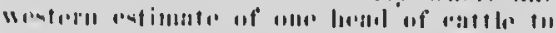

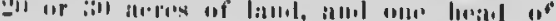

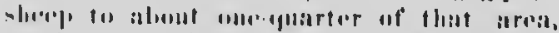

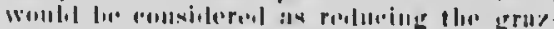

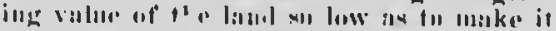

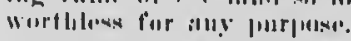

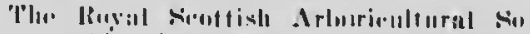

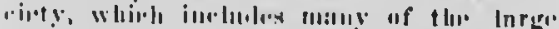

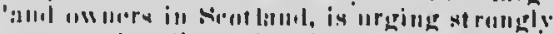

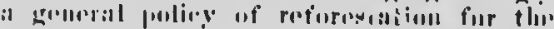

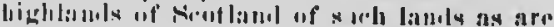

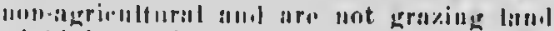

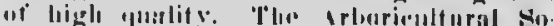

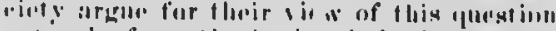

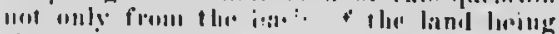

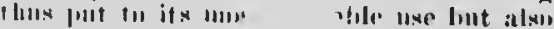

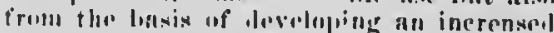

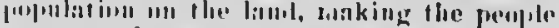

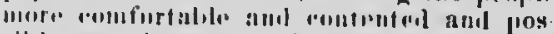

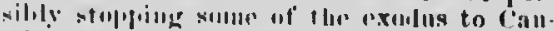

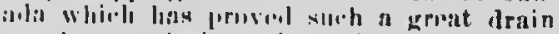

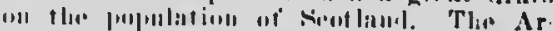

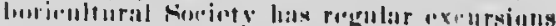

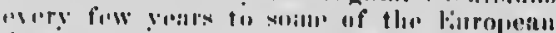

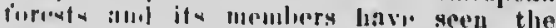
offent on the arinlifincut of population of a well regulated co-operation between 


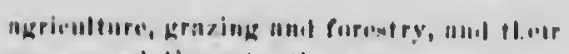

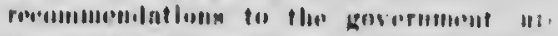

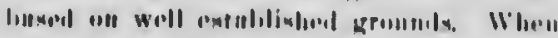

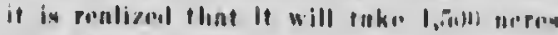

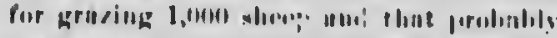

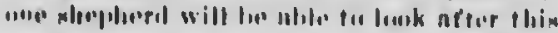

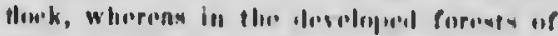

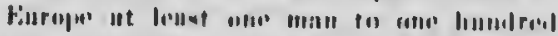

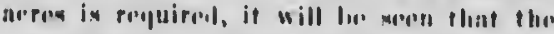

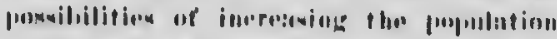

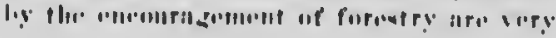
aront.

\section{Conclunion.}

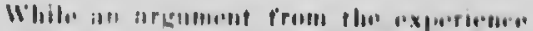

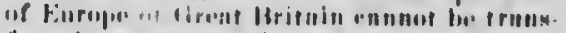

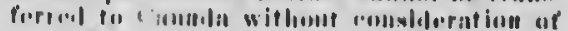

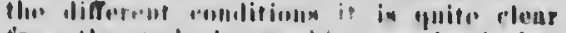

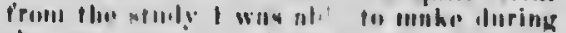

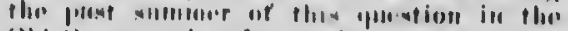

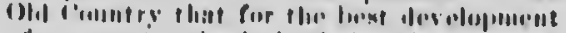
of " coundery lenth in imoluseries mul in

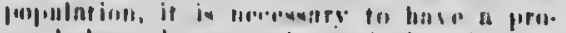

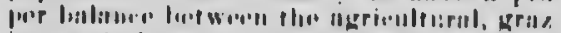

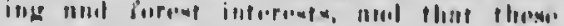

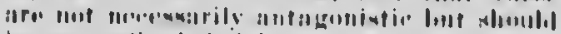

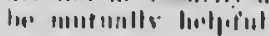

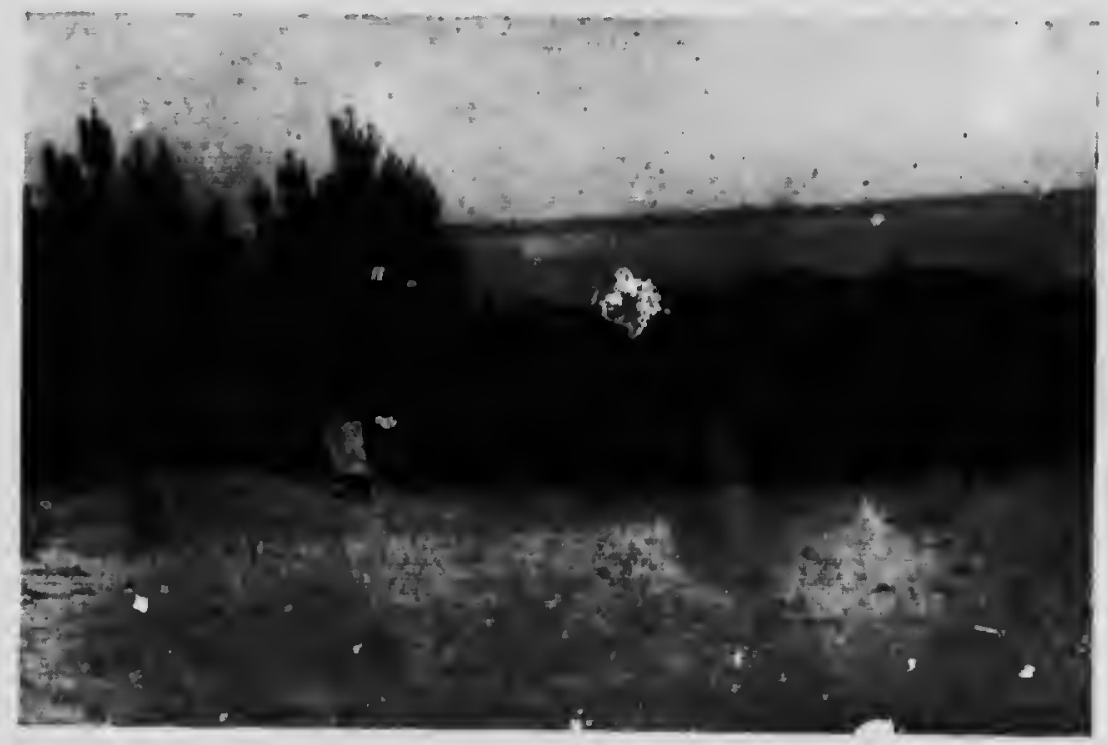

Fire Lille on Sand Dunes near Bordcaux France. 


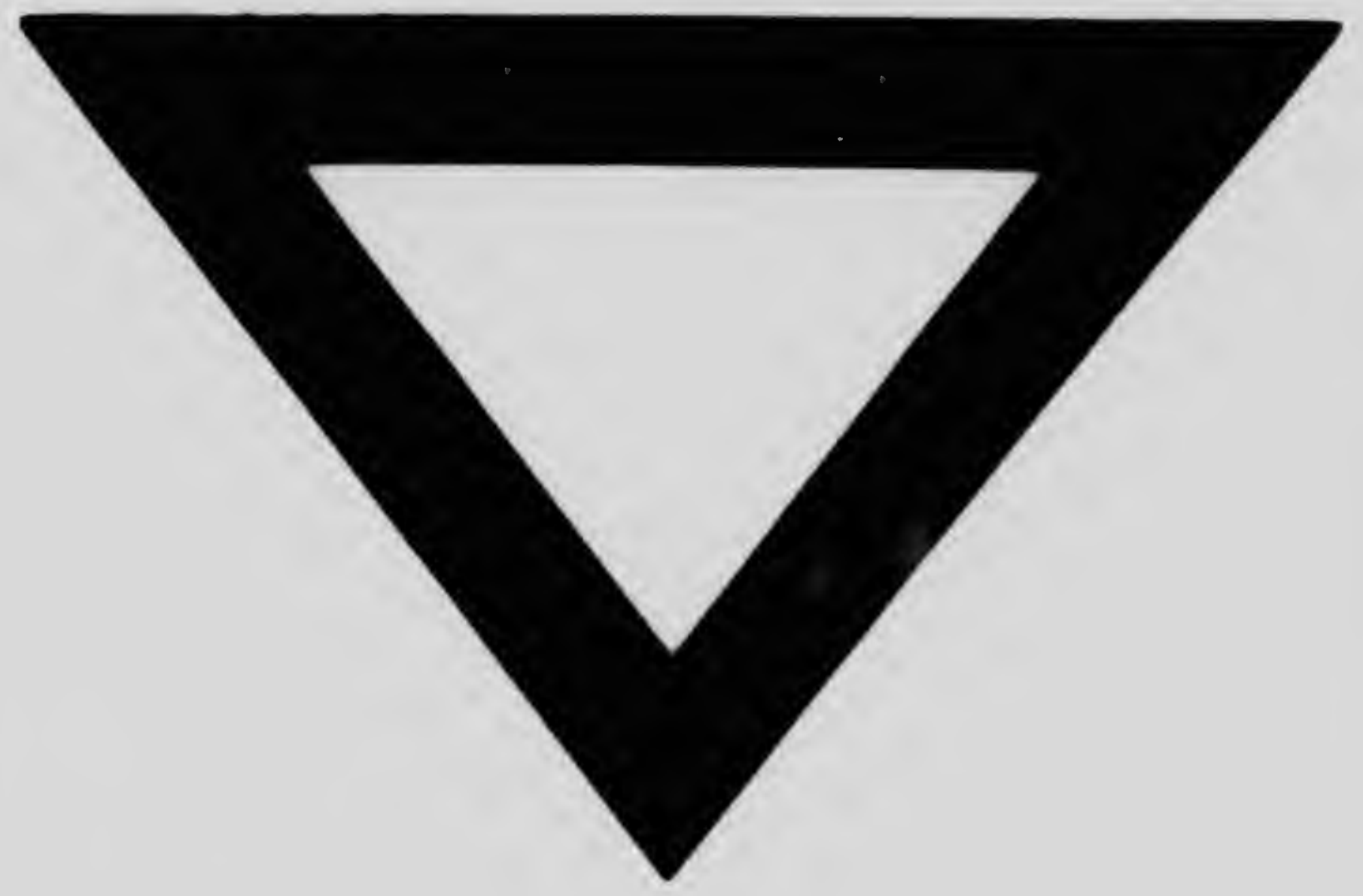

